\title{
Efektivitas Terapi EFT untuk Menurunkan Kecemasan Menghadapi Penyakit Degeneratif pada Lansia Ditinjau dari Dukungan Sosial
}

\author{
Rohmatul Fitri ${ }^{1}$, Suroso ${ }^{2}$, Niken Titi Prastiti ${ }^{3}$ \\ rohmatulfitri.rf45@gmail.com \\ Universitas 17 Agustus 1945 Surabaya
}

\begin{abstract}
Elderly is a phase of reduced physical ability and the emergence of various diseases that affect psychological conditions, one of which is anxiety. The same thing is experienced by Further age who have low social support. Lack of attention and affection can increase anxiety. One therapy that can be used is the Emotional freedom technique (EFT). This study uses an experimental approach with the pretestposttest control group design technique. The random sampling method is used to select 20 subjects based on several criteria. Based on the results of identification conducted by researchers found that 20 participants experienced high and moderate anxiety where 10 participants had moderate to high social support, while 10 participants had low social support. Subjects were divided into two groups: the experimental group and the control group. The results showed that there was a very significant correlation between EF and Anxiety which meant that the higher the EF value, the anxiety would decrease. The results of the second hypothesis are concluded that there is no difference in anxiety both those who have high or low social support. Social support is also influenced by each individual's perception.
\end{abstract}

Keywords: EFT Therapy, Anxiety, Elderly, Social Support

\begin{abstract}
ABSTRAK
Lanjut usia merupakan fase berkurangnya kemampuan fisik dan munculnya berbagai penyakit sehingga mempengaruhi keadaan psikologis salah satunya adalah kecemasan. Hal yang sama juga dialami oleh Lanjut usia yang mempunyai dukungan sosial rendah. Kurangnya perhatian dan kasih sayang mampu untuk meningkatkan kecemasan yang dialami. Salah satu terapi yang bisa digunakan adalah Emotional freedom technique (EFT). Penelitian ini menggunakan pendekatan eksperimen dengan teknik pretest-postest control group design. Metode random sampling digunakan untuk memilih 20 subjek berdasarkan beberapa kriteria. Berdasarkan hasil identifikasi yang dilakukan oleh peneliti ditemukan bahwa 20 peserta mengalami kecemasan tinggi dan sedang dimana 10 peserta mempunyai dukungan sosial yang
\end{abstract}


sedang sampai tinggi, sedangkan 10 peserta mempunyai dukungan sosial yang rendah. Subjek dibagi menjadi dua kelompok yaitu kelompok eksperimen dan kelompok kontrol. Hasil penelitian menunjukkan bahwa adanya korelasi yang sangat signifikan antara EF dengan Kecemasan yang berarti bahwa semakin tinggi nilai EF maka kecemasan akan semakin berkurang. Hasil dari hipotesa kedua diperoleh kesimpulan bahwa tidak ada beda kecemasan baik yang mempunyai dukungan sosial tinggi maupun rendah. Dukungan sosial juga dipengaruhi oleh persepsi setiap individu.

\section{Kata kunci : Terapi EFT, Kecemasan, Lansia, Dukungan Sosial}

\section{PENDAHULUAN}

Lanjut usia merupakan perkembangan akhir pada rentang kehidupan manusia yang tidak dapat dihindari. Papalia (2014) menjelaskan bahwa ketika seseorang berada pada fase lanjut usia, kemampuan fungsi tubuh dan kondisi psikologis akan semakin menurun. sehingga banyak perubahan yang dialami dari segi fisik, emosi maupun kemampuan kognitif. Meskipun hal ini normalnya dikarenakan adanya penurunan otak secara halus, akan tetapi sebagian besar lansia pada umumnya mempunyai kekenyalan otak yang dapat mengatur kembali sirkuit neural untuk merespons tantangan penuaan yang bersifat neurobiologis (Park \& Gutchess, 2006). Selain itu, lansia juga dapat mengalami penurunan pada fungsi sensoris dan motorik dan juga penglihatan serta pendengaran.

Dijelaskan pula oleh Santrock (2002) bahwa di usia lanjut juga terjadi penurunan fisik yang lebih besar dibandingkan periode-periode usia sebelumnya. Hal ini dipertegas oleh Farhand (dalam Listiana, dkk, 2013) bahwa proses menua (aging) merupakan proses alami yang disertai adanya penurunan kondisi fisik, psikologis maupun sosial yang saling bersinteraksi satu sama lain. Hasil riset kesehatan dasar (Riskesdas, 2013), mengungkapkan bahwa penyakit terbanyak pada lanjut usia adalah penyakit tidak menular (PTM) antara lain hipertensi, artitris, stroke, penyakit paru obstruktif kronik (PPOK) dan diabetes mellitus (DM). Riset yang sama juga dilakukan di Amerika Serikat (Papalia, 2014) bahwa pada umunya enam dari tujuh 
penyebab utama kematian pada usia tua adalah kondisi kronis seperti penyakit jantung, kanker, stroke, penyakit pernafasan kronis, diabetes, dan influenza atau pneumonia (Papalia, 2014). Faktanya di negara Amerika, penyakit jantung, kanker dan stroke menyumbang sekitar 60\% kematian diantara penduduk tua (Federal Interagency Forum on Aging-Related statistic, 2006; 2007). Bahkan diseluruh dunia, penyebab utama kematian pada usia 60 tahun keatas adalah penyakit jantung, stroke, penyakit paru-paru kronis, infeksi pernafasan bawah, dan kanker paru-paru (WHO, 2003).

Berbagai penyakit yang dialami oleh orang dengan lanjut usia telah mempengaruhi keadaan psikologis. Gangguan psikologis yang sering dialami oleh lansia seperti stres, depresi dan termasuk juga anxiety (Annisa \& Ifdil, 2016). Dijelaskan lebih lanjut oleh Annisa dan Ifdil bahwa orang usia lanjut memiliki kemungkinan yang lebih tinggi untuk mengalami gangguan-gangguan kecemasan daripada depresi. Bahkan menurut Heningsih (2014) masalah psikososial yang paling banyak terjadi pada lansia meliputi, kesepian, perasaan sedih, depresi dan kecemasan. Disinilah dukungan keluarga seperti anak dan sanak saudara sangat berpengaruh pada kondisi emosi orang dengan lanjut usia. Seperti dinyatakan Papalia (2014) bahwa dukungan emosional dapat membantu lansia dalam mempertahankan kepuasan hidup ketika menghadapi stres dan trauma, seperti kehilangan pasangan hidup atau anak atau kecelakaan dan penyakit yang mengancam kehidupan ada ikatan positif dengan kesehatan dan kebahagiaan hidup yang lebih baik.

Observasi dan wawancara awal yang dilakukan di Posyandu Lansia Puskesmas Dukuh Kupang Surabaya pada bulan Mei 2019 juga menunjukkan pentingnya dukungan sosial. Enam lansia yang diobservasi dan diwawancara tersebut sebagian besar mengemukakan tentang kecemasan mereka atas kondisi kesehatan serta mengeluhkan tentang minimnya kepedulian anak-anak mereka terhadap kondisi mereka. Beberapa diantaranya mengeluhkan masih harus terlibat dengan kehidupan anak karena mengurus cucu sehingga minim istirahat. Berbeda dengan sebagian peserta yang mendapatkan dukungan sosial dari keluarga, umumnya lebih merasa 
tenang karena orang terdekat selalu merawat kesehatan Lansia dengan mengantarkan untuk pergi kontrol kesehatan. Meskipun para Lansia masih merasakan kecemasan tentang kondisi tubuh yang semakin menurun, lansia yang mendapatkan dukungan sosial masih memiliki keluarga dekat yang berempati. Fakta yang diperoleh dari observasi tersebut, mendukung hasil riset yang dilakukan oleh Taha (2013) yang menunjukkan bahwa hubungan sosial yang erat sangat berpengaruh terhadap tingkat kecemasan pada lansia.

Penelitian lain yang dilakukan oleh Eng, Rimm, Fitzmaurice, \& Kawachi (2002) secara longitudinal (10 tahun) pada 28.396 laki-laki, yang terisolasi secara sosial 53 persen lebih mungkin meninggal akibat penyakit kardiovaskular dan dua kali lebih mungkin untuk meninggal akibat kecelakaan atau bunuh diri dibandingkan laki-laki yang terhubung secara sosial. Riset yang sama menunjukkan bahwa untuk perempuan lanjut usia, yang sering kali merupakan janda dan hidup sendiri, dukungan emosional juga sangat penting. Dijelaskan pada penelitian yang dilakukan di Finlandia tersebut, menunjukkan bahwa Lansia perempuan yang menerima dukungan yang paling khusus seperti perasaan dibutuhkan dan dihargai, rasa memiliki, dan keintiman emosional 2,5 kali lebih kecil kemungkinan untuk meninggal dalam periode penelitian dibandingkan dengan mereka yang tidak menerima dukungan sosial.

Adanya dukungan sosial dapat menjadi indikator informasi bahwa seseorang yang merasa dicintai, diperhatikan, memiliki harga diri dan dihargai melalui jaringan komunikasi dan kewajiban bersama (Taha, 2013). Dukungan sosial menjadi penting bagi lansia karena umumnya mereka mempunyai masalah yang kompleks, tidak adanya pengobatan sederhana bagi penyakit mereka, penurunan kemandirian, dan dibutuhkannya bantuan orang lain dalam perawatan (Jafar, 2011). Oleh karena itu, pengunaan sistem dukungan sosial keluarga atau individu harus menjadi bagian integral dari perawatan kesehatan keluarga maupun di panti sosial (Kelley.et.al.1997). 
Terapi untuk menurunkan kecemasan pada Lansia dibutuhkan untuk meningkatkan kesejahteraan hidup Lansia. Teknik Emotional Freedom Technique (EFT) menggunakan kalimat penerimaan diri yang dipadukan dengan mengetuk ringan (tapping) titik -titik meridian tubuh untuk mengirim sinyal yang bertujuan untuk menenangkan otak (Ningsih, 2015). Mengetuk ringan dengan satu atau dua ujung jari pada titik akupuntur sama efektifnya dengan stimulasi pada praktek akupuntur, oleh karena itu orang menyebut EFT dengan akupuntur tanpa jarum. Titik meridian dijelaskan lebih lanjut, merupakan titik pada jaringan tubuh yang mempunyai jaringan padat dan bertempat diujung-ujung syaraf. Titik meridian ternyata mempunyai potensial elektrik yang tinggi dibanding dengan titik lain di tubuh.

Ketukan yang dilakukan pada titik tubuh dapat menimbulkan respon melalui jaringan sensorik sampai melibatkan saraf sentral (Saputra \& Sugeng, 2012). Dijelaskan lebih lanjut bahwa jaringan saraf berkomunikasi satu dengan yang lain melalui neurotransmitter di sinapsis. Stimulasi terhadap jaringan saraf di perifer akan berlanjut ke sentral melalui medula spinalis batang otak menuju hipotalamus, dan hipofisis. Stimulasi dari perifer akan disampaikan ke otak hipotalamus berefek terhadap sekresi neurotransmitter seperti $\beta$-endorfin, norepinefrin dan enkefalin, 5$H T$ yang berperan sebagai inhibisi sensasi nyeri. Sekresi neurotransmiter ini juga berperan dalam sistem imun sebagai imunomodulator serta perbaikan fungsi organ lainnya seperti pada penyakit psikiatrik (Saputra\& Sugeng, 2012).

Tujuan EFT adalah untuk melepaskan emosi-emosi negatif sehingga tidak lagi mengganggu kehidupan seseorang dan menggantikannya dengan emosi yang lebih positif (Iskandar, 2010). Selain itu, gerakan yang sederhana tanpa membutuhkan alat apapun memungkinkan seseorang lansia untuk mempraktekan sendiri di rumah. 


\section{METODE PENELITIAN}

Desain penelitian yang digunakan adalah true eksperimen dengan metode pretest posttest control group design. Pemilihan sampel pada penelitian ini menggunakan metode random sampling dengan membatasi sampel yaitu subjek berumur 60 tahun keatas, belum mempunyai penyakit hereditas yang parah, dan mengalami kecemasan menghadapi penyakit degeneratif.

Penelitian ini melibatkan dua kelompok yaitu kelompok eksperimen dan kelompok kontrol. Pada kelompok eksperimen dilakukan pengukuran sebelum diberikan intervensi (Pre test) dan dilakukan pengukuran setelah diberikan intervensi (post test). Sedangkan pada kelompok kontrol tidak dilakukan intervensi namun tetap dilakukan pengukuran pre-test dan post-test (Ningsih, 2015).

Peneliti memberikan skala kecemasan, dukungan sosial dan EF (emotional freedom) kepada 36 peserta posyandu Lansia. Peneliti memberikan kategori sangat rendah, rendah, sedang, tinggi, dan sangat tinggi pada skala kecemasan dan dukungan sosial. kategori tersebut didapatkan dari hasil mean dari jumlah skala yang diberikan kepada peserta.

Berdasarkan hasil identifikasi yang dilakukan oleh peneliti ditemukan bahwa 20 peserta mengalami kecemasan tinggi dan sedang dimana 10 peserta mempunyai dukungan sosial yang sedang sampai tinggi, sedangkan 10 peserta mempunyai dukungan sosial yang rendah. 


\section{HASIL PENELITIAN}

Hasil analisa data statistic nonparametik SPSS Statistic Version 16 dengan teknik Anova Oneway menguji tentang adanya pengaruh terapi EFT terhadap penurunan tingkat kecemasan. Hasil dari analisis tersebut adalah sebagai berikut:

Tabel 10 Uji Anova Oneway

\begin{tabular}{ccc}
\hline & $\mathrm{F}$ & $\mathrm{P}$ \\
\hline Kecemasan & 571,028 & 0,00 \\
\hline
\end{tabular}

Berdasarkan tabel diatas diperoleh bahwa nilai $\mathrm{p}=0.00(\mathrm{p}<0.05)$ maka dapat disimpulkan bahwa adanya korelasi yang sangat signifikan antara EF dengan Kecemasan yang berarti bahwa semakin tinggi nilai EF maka kecemasan akan semakin berkurang.

Hasil tersebut didukung dengan bukti lain yang diperoleh dari hasil uji korelasi antara kecemasan pada Lansia dengan skala EF yaitu rxy= -0,88 dan p= 0,002 yang menunjukkan bahwa ada korelasi negatif yang siginifikan antara EF dengan kecemasan, maknanya semakin seseorang mampu mengendalikan emosi maka semakin rendah kecemasan. Sehingga hipotesis satu dapat diterima.

Hipotesis kedua menguji ada beda tingkat penurunan kecemasan pada Lansia yang mempunyai dukungan sosial sedang sampai tinggi dan Lansia yang mempunyai dukungan sosial rendah. Pada hipotesis ini menggunakan statitistik nonparametrik SPSS 16 dengan teknik Anova oneway.

Tabel 11. Uji analisis Anova Oneway

\begin{tabular}{lccc}
\hline & $\mathrm{f}$ & $\mathrm{P}$ \\
\hline Kecemasan & 0,750 & 0,651 & \\
\hline
\end{tabular}


Berdasarkan tabel diatas dapat diperoleh kesimpulan bahwa f yang dihasilkan sebesar $\mathrm{f}=0,750$ dengan signifikansi $0.651(\mathrm{p}>0.05)$ maka dapat disimpulkan bahwa tidak ada beda tingkat kecemasan pada Lansia yang mempunyai dukungan sosial sedang sampai tinggi dan Lansia yang mempunyai dukungan sosial rendah setelah diberikan terapi EFT.

\section{PEMBAHASAN}

Hasil penelitian menunjukkan bahwa nilai $\mathrm{p}=0,00(\mathrm{p}<0,05)$ yang berarti terapi EFT sangat efektif untuk menurunkan kecemasan pada Lansia. Hasil tersebut dikuatkan dengan nilai korelasi antara kecemasan dan EF yaitu $\mathrm{rxy}=-0,881$ dan $\mathrm{p}=$ 0,002 yang menunjukkan bahwa ada korelasi negatif yang siginifikan antara EF dengan kecemasan. Korelasi negatif yang terjadi mengartikan bahwa semakin tinggi seseorang mampu membebaskan emosi, maka kecemasan akan semakin berkurang.

Berkurangnya kecemasan pada Lansia dikarenakan terapi EFT mampu untuk memberikan rasa tenang setelah seseorang membebaskan emosi dan melakukan tapping ringan (Shari, 2014). Selanjutnya dijelaskan bahwa dengan mengetuk titik meridian, maka akan terjadi pembebasan energi sehingga tubuh semakin rileks dan tidak terasa tegang. Pembebasan emosi yang terdapat dalam EFT mempunyai tujuan untuk memfokuskan fikiran-fikiran negatif pada otak untuk kemudian dilepaskan (Bougea, 2013) begitupula dengan kecemasan yang dialami oleh Lansia.

Energi meridian adalah jalur lalu lintas energi didalam tubuh. Seperti halnya lalu lintas, pada Meredianpun ada jalur, hambatan, persimpangan, titik awal, titik akhir, dan sebagainya. Jika jalan energi lancar, akan tercipta keharmonisan dalam tubuh dan tubuh kita mampu melawan penyakit. Sebaliknya, jika terjadi hambatan pada meridian, akan muncul gangguan pada kesehatan (Iskandar, 2010). Menurut Iskandar letak meridian didalam tubuh bervariasi, bergantung pada jalurnya. Jalur meridian ada yang melewati sela-sela tulang, ada yang berada di sela-sela otot, dan karena wujudnya yang tidak nyata ada juga yang menembus atau menyelimuti organ. Bahkan ada jalur meridian yang muncul dekat dengan permukaan kulit. 
Setiap jalur meridian yang di ketuk mempunyai fungsinya masing-masing. Berikut beberapa titik meridian beserta fungsinya masing-masing:

a. Crown Point (CP) Dalam akupuntur disebut dengan titik baihui atau disebut dengan hudred meeting point, berada dalam governing vesei meridian. Fungsi utama titiktitik ini adalah untuk mengatasi sakit kepala, vertigo, tinnitus, opstruksi hidung, aphasia, karena apoleksia, koma, gangguan jiwa, prolapses rectum dan uterus.

b. Eyes Brows Point (EB) dalam akupuntur disebut dengan titik cuanzu atau disebut dengan gathered bamboo point, berada dalam bladder meridian. Fungsi utama titik ini adalah untuk mengatasi sakit kepala, penglihatan kabur, nyeri didaerah supraorbital, lakriminasi, kemerahan, pembengkakan, dan nyeri mata, kejang pada kelopak mata, spasme otot mata (kedutan), juga untuk manic depressive.

c. Side of Eyes Point (SE) dalam akupuntur disebut dengan titik tongzilio, berada dalam gallbladder meridian. Fungsi utama titik ini adalah untuk mengatasi sakit kepala kemerahan pada mata dan nyeri mata, gangguan penglihatan, lakrimasi, deviasi mata dan mulut.

d. Under Eyes Point (UE) dalam akupuntur disebut dengan titik chengi berada dalam stomach meridian. Fungsi utama titik ini adalah untuk mengatasi kemerahan dan nyeri pada myopia, paralisis fasalis, kejang otot mata, konjungtivis, rabun senja, mengatasi masuk angina, bells palsy, dan bergetarnya kelopak mata.

e. Under Nose Point (UN) dalam akupuntur disebut dengan titik shuigou, disebut juga dengan ren chung, atau selokan air mata atau pusat manusia. Titik ini berada dalam governing vessel meridian. Fungsi utama titik ini adalah untuk shock, kolaps, sengatan matahari koma, skizofrenia, manic depressive disorder, meningkatkan kecerdasan dan kejang pada anak.

f. Chint Point $(\mathrm{CH})$ dalam akupuntur disebut dengan titik chengjjang. Titik ini merupakan pertemuan antara meridian rend an meridian lambung, titik ini berada pada conceptions vessel meridian. Fungsi utama titik ini adalah untuk paralis fasialis, pembengkakan gusi, sakit gigi, nyeri saat menstruasi, gangguan andrologi pri, gangguan pencernaan dan salivasi berlebihan. 
g. Collar Bone Point (CB) dalam akupuntur disebut dengan titik qishe, disebut juga rumah $Q i$ yang artinya pertemuan dari aliran energy, titik ini berada pada stomach meridian. Fungsi utama titik ini adalah untuk sakit tenggorokan, batuk, cegukan, asma, scrofula, nyeri dada dan gangguan manic depression

h. Under Arm Point (UA) dalam akupuntur disebut dengan titik dabao, disebut juga titik sampul besar yang artinya pertemuan dari meridian limpa, titik ini berada dalam spleen meridian. Fungsi utama titik ini adalah untuk nyeri seluruh tubuh, kelelahan kronis, dan nyeri di daerah dada.

i. Karate Chop Point dalam akupuntur titik ini disebut dengan titik houxi, titik ini berada dalam small intestine meridian. Fungsi utama dari titik ini adalah nyeri dana kekauan leher, sakit kepala, neuralgia, intercostalis, tinnitus, dan sakit tenggorokan.

Selain manfaat fisik yang dirasakan, EFT yang dilakukan juga membantu untuk menurunkan kecemasan. Sate up statement yang dikatakan ketika mengetuk titik karate dibagian kiri atas atau kanan atas dada mampu untuk menjadi sugesti bagi diri individu untuk menurunkan kecemasan yang dialami.

Dilain sisi, hasil penelitian yang dilakukan tidak sesuai dengan hipotesa kedua yang menyatakan bahwa ada perbedaan tingkat penurunan kecemasan antara Lansia dengan dukungan sedang sampai tinggi dan Lansia dengan dukungan sosial rendah setelah mendapatkan terapi EFT. Hasil penelitian menyatakan bahwa tidak ada perbedaan penurunan tingkat kecemasan antara Lansia dengan dukungan sedang sampai tinggi dan Lansia yang mendapatkan dukungan rendah setelah mendapatkan terapi EFT. Kesamaan yang dihasilkan disebabkan bahwa dukungan sosial juga dipengaruhi oleh persepsi setiap individu. Persepsi terhadap dukungan sosial adalah penilaian secara kognitif dan afektif berdasarkan pengalaman bersama keluarga dan teman mengenai dukungan emosional, informasi, instrumental dan penghargaan (Desiningrum, 2014). Seseorang yang mempersepsikan dukungan sosial yang diperoleh dari lingkungan secara positif akan menganggap peristiwa yang dialami menjadi suatu hal yang tidak terlallu mendatangkan stres dan merasa aman serta 
nyaman karena merasa diperhatikan, dicintai dan dirinya dapat diterima di lingkungan dengan baik (Amylia, 2014). Dijelaskan lebih lanjut bahwa jika dukungan sosial yang diperoleh dari lingkungan diinterpretasi sebagai hal yang biasa saja tanpa ada respon yang positif, maka dukungan tersebut menjadi tidak efektif dan seseorang merasa tidak nyaman karena tidak dapat membalas dukungan yang diberikan atau percaya bahwa kontrol pribadinya dibatasi oleh dukungan sosial.

Dukungan sosial tidak hanya bisa diperoleh dari keluarga dekat. Lansia posyandu among tresno yang merasa kurang diperhatikan oleh keluarga masih beranggapan bahwa ada teman-teman sekitar yang saling mendukung. Peserta akan berkumpul setiap minggu bisa menceritakan keluh kesah pada sesama maupun petugas posyandu, selain itu, peserta juga merasa mempunyai Petugas kesehatan yang memperhatikan kesehatan sehingga membuat peserta merasa terpenuhi akan kebutuhan untuk diperhatikan.

Hasil ini diperkuat oleh Penelitian yang dilakukan oleh Kim \& Moen (2007) terhadap lansia disejumlah negara di Asia Tenggara, menemukan bahwa dukungan emosional terbesar yang mereka dapatkan berasal dari teman-teman dan tetangga $(55,7 \%)$, diikuti oleh dukungan dari anggota keluarga $(36,5 \%)$. 


\section{DAFTAR PUSTAKA}

Almasitoh, U. H (2011). Stres Kerja Ditinjau dari Konflik Peran Ganda dan Dukungan Sosial pada Perawat. Psikoislamika, Jurnal Psikologi Islam (JPI). $8,63-82$.

Amylia, Y., \& Surjaningrum, E. (2014). Hubungan antara persepsi dukungan sosial dengan tingkat kecemasan pada penderita Leukimia. Jurnal Psikologi Klinis dan Kesehatan Mental, 3, 79-84

Anisa, F. D., Ifdil. (2016). Konsep Kecemasan (Anxiety) pada Lanjut Usia (Lansia). Konselor, 5, 93-99.

Boeree, C. G. (2016). Personality Theories. Jogjakarta: Prismasophie

Bougea, A.M., Spandises, M. N., Evangelos, C. S., et al. (2013). Effect Of The Emotional Freedom Technique On Perceived Stress, Quality Of Life, And Cortisol Salivary Levels In Tension-Type Headache Sufferers: A Randomized Controlled Trial. Explore 2013, 9, 91-99.

Desiningrum, D. R. (2014). Kesejahteraan Psikologis Lansia janda/duda ditinjau dari persepsi terhadap dukungan sosial dan gender. Jurnal psikologi Undip, 13, 102-106.

Gould, L. R., Coulson, C. M., Howard. J. R., (2012). Efficacy of Cognitive Behavioral Therapy for Anxiety Disorders in Older People: A Meta-Analysis and Meta-Regression of Randomized Controlled Trials. The American Geriatrics Society. 60, 218-229. 
Handajayani, A., Rosihermiatie, B., Maryani, H. (2010). Faktor-faktor yang berhubungan dengan pola kematian pada penyakit degenerative di Indonesia. Bulletin penelitian Sistem kesehatan, 13, 42-53.

Hurlock, E. B. (1980). Psikologi Perkembangan: suatu pendekatan sepanjang rentang kehidupan. Jakarta : Erlangga.

Iskandar, E. (2010). The Miracle of Touch panduan menerapkan kejaiban EFT untuk kesehatan, kesuksesan, dan kebahagiaan anda. Bandung: PT Mizan Pustaka.

Jafar, N., Wiarsih, W. Permatasari, H. (2011). Pengalaman Lanjut Usia Mendapatkan Dukungan Keluarga. Jurnal Keperawatan Indonesia, 14, 157-164.

Latipun. (2017). Psikologi Eksperimen. Malang: Universitas Muhammadiah Malang.

Marni, A., \& Yuniawati, R. (2015). Hubungan Antara Dukungan Sosial Dengan Penerimaan Diri Pada Lansia Di Panti Wredha Budhi Dharma Yogyakarta. Empathy, Jurnal Fakultas Psikologi. 3, 1-7.

Ningsih, S. F., Karim, D., \& Sabrian, F. (2015). Efektivitas Terapi Emotional Freedom Technique (Eft) Terhadap Kecemasan Pasien Kanker Payudara Stadium II Dan III. JOM 2, 1501-1509.

Noel, P. H., William, J. W., Unutzer, J. (2004). Depression and comorbid illness in elderly primary care patients: impact on multiple domains of health status and well-being. Annal of Family Medicine, 2, 555-562

Orimo, H., dkk (2006). Reviewing the definition of "elderly". Japan Geriatrics Society. 6, 149-158. 
Papalia, E. D., Feldman, D. R. (2014). Menyelami Perkembangan Manusia Edisi 12. Jakarta: Salemba Humanika.

Ray, O. (2004). How the mind hurts and heals the body. American Psychologist, 59. $29-40$

Richman, L. S., Kubzansky, L., Maselko, J., Kawachi, I., et al. (2005). Positive Emotion and health: Going Beyond the negative. Health Psychology, 24, 422429.

Rohmah, A, P. Bariyah, K. (2012). Kualitas Hidup Lanjut Usia. Jurnal Keperawatan. $3,157-164$.

Saputra, A., Sugeng, J. (2012). Buku terapi EFT (emotional freedom technique). Yogyakarta: NQ Publishing.

Santrock, J, W. (2002). Life-Span Development. Perkembangan masa hidup. Jakarta: Erlangga NQ Publishing.

Sarafino, E, P. (2002). Health Psychology Biopsychosocial Interactions, (4th ed.). United State: John Wiley \& Sons, Inc,

Seniati, L. Y. A., Setiadi, N. B. (2018). Psikologi Eksperimen. Jakarta: Indeks

Shari, Weni. W., Suryani, E. E. (2014). Emotional Freedom Techniques dan Tingkat Kecemasan Pasien yang akan Menjalani Percutaneous Coronary Intervention. PSIK Fakultas Kedokteran Universitas Sriwijaya, 2, 133-145. 
Zainudding, F. A. (2012). SEFT ESSENTIALS The Simplest Way to Get Healed. Surabaya: SEFT Corporation.

Zainuddin, F. A. (2008). Spritual Emotional Freedom Technique (SEFT). Jakarta: PT.Arga Publishing. 